\title{
HBx Sensitizes Cells to Oxidative Stress-induced Apoptosis by Accelerating the Loss of Mcl-1 Protein via Caspase-3 Cascade
}

Liang $\mathrm{Hu}^{1+}$, Lei Chen ${ }^{1 \dagger}$, GuangZhen Yang ${ }^{1+}$, Liang $\mathrm{Li}^{1}$, HanYong Sun ${ }^{1}$, YanXin Chang ${ }^{1}$, QianQian Tu${ }^{1}$, MengChao $\mathrm{Wu}^{2}$ and HongYang Wang ${ }^{1,3^{*}}$

\begin{abstract}
Background: Oxidative stress has been implicated in the pathogenesis of a wide spectrum of human diseases, including Hepatitis B virus (HBV)-related liver disease. Hepatitis B virus X protein ( $\mathrm{HBX}$ ) is a key regulator of HBV that exerts pleiotropic activity on cellular functions. Recent studies showed that HBx alters mitochondrial membrane potential, thereby sensitizing cells to pro-apoptotic signals. However, it remains largely unknown whether susceptibility of hepatocytes could be disturbed by HBx under oxidative stress conditions. The purpose of this study is to determine the apoptotic susceptibility of HBx-expressing hepatocytes upon exposure to pro-oxidant stimuli in vitro and in vivo and explore its underlying mechanism.
\end{abstract}

Results: Although expression of HBx itself did not activate apoptotic signaling, it significantly enhanced oxidative stress-induced cell death both in vitro and in vivo. Interestingly, this phenomenon was associated with a pronounced reduction of protein levels of Mcl-1, but not other anti-apoptotic BCl-2 members. Importantly, enforced expression of Mcl-1 prevented HBx-triggered cell apoptosis; conversely, specific knockdown of Mcl-1 exacerbated HBx-induced apoptosis upon exposure to oxidative stress. Furthermore, inhibition of caspase-3 not only abrogated HBx-triggered apoptotic killing but also blocked HBx-induced Mcl-1 loss. Additionally, expression of $\mathrm{HBx}$ and MCl-1 was found to be inversely correlated in HBV-related hepatocellular carcinogenesis (HCC) tissues.

Conclusions: Our findings indicate that $\mathrm{HBx}$ exerts pro-apoptotic effect upon exposure to oxidative stress probably through accelerating the loss of Mcl-1 protein via caspase-3 cascade, which may shed a new light on the molecular mechanism of HBV-related hepatocarcinogenesis.

\section{Background}

Chronic Hepatitis B virus (HBV) infection is a major risk factor of human chronic liver disease and is strongly associated with hepatocellular carcinogenesis (HCC). Among the $\mathrm{HBV}$ encoding proteins, HBV X protein $(\mathrm{HBx})$ is considered as a critical viral protein that exhibits multifunctional activities in modulating gene transcription, protein degradation, signal transduction, cell proliferation, cell cycle progress, senescence, autophagy and apoptosis [1-4].

\footnotetext{
* Correspondence: hywangk@vip.sina.com

† Contributed equally

${ }^{1}$ International Co-operation Laboratory on Signal Transduction, Eastern Hepatobiliary Surgery Institute, Second Military Medical University, Shanghai, China

Full list of author information is available at the end of the article
}

Since apoptosis has been implicated as an important mechanism for liver injury [5,6], much effort has been made to understand the role of $\mathrm{HBx}$ in the regulation of apoptosis and its contribution to HCC. To date, the reported effects of $\mathrm{HBx}$ on apoptosis are controversial. As reported previously, the discrepancy of the role of $\mathrm{HBx}$ on cell apoptosis may be due to the different culture conditions and experimental systems used in these studies. Nevertheless, majority of these studies demonstrated that HBx can induce cell death or sensitize hepatocytes to a variety of apoptotic signals such as TNF- $\alpha$, TRAIL, vitamin K3, ethanol, Fas, and UV [7-12]. In experimental animals, HBx transgenic mice also exhibit increased hepatic apoptosis [13].

It is well known that oxidative stress have been implicated in the pathogenesis of inflammatory diseases and
C Biomed Central

C 2011 Hu et al; licensee BioMed Central Ltd. This is an Open Access article distributed under the terms of the Creative Commons Attribution License (http://creativecommons.org/licenses/by/2.0), which permits unrestricted use, distribution, and reproduction in any medium, provided the original work is properly cited. 
cancer [14] and reactive oxygen species (ROS) are continuously generated within chronic inflammation and malignant tumor tissues. In addition, infiltration of activated phagocytic cells in liver disease provides another source of ROS production that promotes oxidative damage to hepatocytes [15]. Recent work showed that HBx expression could alter mitochondrial membrane potential and increase cellular ROS production, thereby sensitizing hepatoma cells to apoptotic stimuli $[9,16]$. Consistent with these in vitro findings, HBV transgenic mice also display elevated oxidative stress levels in the liver as compared to the nontransgenic control strain [17]. Thus, it is possible that, in HBV-infected liver, $\mathrm{HBx}$ protein and oxidative signals generated within the microenvironment may cooperate to increase cellular ROS accumulation up to a deleterious level, thereby resulting in overt liver cell damage. However, relatively little research has addressed the issue of whether susceptibility of hepatocytes upon exposure to oxidative stress could be affected by HBx.

The Bcl-2 protein family plays a pivotal role for mitochondrial membrane integrity and apoptosis regulation $[18,19]$. Among them, Mcl-1 is both structurally and functionally an anti-apoptotic member of the Bcl-2 family. It mainly locates on the outer membrane of mitochondria and is an important regulator of mitochondria-mediated apoptosis by preventing the release of cytochrome c into cytosol [20]. Recently, it has been demonstrated that Mcl-1 plays a key role in regulation of apoptosis and survival in multiple tissues and cell lines $[21,22]$. It is frequently overexpressed in several human malignancies such as multiple myeloma, nonsmall cell lung cancer and HCC. Knock down Mcl-1 protein expression sensitizes HCC cells towards apoptosis induction [23,24]. Using a conditional knock-out animal model, Schulze-Bergkamen $\mathrm{H}$ and his team demonstrated that hepatocyte-specific deletion of Mcl1 not only increases spontaneous hepatocyte apoptosis resulting in profound liver cell damage and increases susceptibility of hepatocytes to pro-apoptotic stimuli [25], but also, more importantly, triggers hepatocellular proliferation and causes HCC [26]. Results from previous studies showed that $\mathrm{H}_{2} \mathrm{O}_{2}$ could abrogate the prosurvival function of Mcl-1 either by diminishing its levels or by inactivating its function $[27,28]$, however, little is known about the potential role of Mcl-1 in $\mathrm{HBx}$-induced cell killing. Given the importance of Mcl-1 in maintaining liver homeostasis, the aim of this work was to determine the apoptotic susceptibility of $\mathrm{HBx}$-expressing hepatocytes under oxidative stress conditions and explore the possible role of Mcl-1 in this process.

Here, we reported that HBx enhanced oxidative stressinduced apoptotic killing both in vitro and in vivo, which is probably through accelerating the loss of Mcl-1 protein via caspase- 3 cascade. Our results may have implications for understanding HBV-related hepatocarcinogenesis.

\section{Results \\ HBx-Tg mice exhibit an increased oxidative stress and apoptotic susceptibility to liver ischemia-reperfusion challenge}

To investigate whether susceptibility of hepatocytes under oxidative stress conditions could be disturbed by $\mathrm{HBx}$ in vivo, $\mathrm{HBx}$ transgenic $(\mathrm{HBx}-\mathrm{Tg})$ mice and wide type (WT) control strain were used (Figure 1A) and subjected to warm liver ischemia-reperfusion (I/R), an animal model which mimics pro-oxidant milieu in vivo. As expected, a decrease in total liver GSH level, an indicator of hepatocyte ROS accumulation, was observed in I/Rtreated WT mice. Notably, an even greater decrease in liver GSH content was detected in I/R-treated $\mathrm{HBx}-\mathrm{Tg}$ mice (Figure 1B). As an important index of oxidative stress, liver GSH/GSSG ratio were also monitored. Similarly, liver I/R treatment caused an even greater dramatic fall in the GSH/GSSG ratio in HBx-Tg mice than WT mice (Figure 1B). To evaluate in situ formation of ROS, the oxidative fluorescent dye dihydroethidine (DHE) was used by a method described by Sakurai T et al [29]. More extensive fluorescence was seen in livers of $\mathrm{HBx}-\mathrm{Tg}$ mice than matched controls after liver I/R treatment (Figure $1 C$ ), indicating that HBx promotes cellular ROS accumulation upon oxidative stress stimulation. Meanwhile, increased hepatocyte apoptosis, as determined by PARP cleavage, was also observed in livers of $\mathrm{HBx}-\mathrm{Tg}$ mice as compared to WT mice following I/R challenge (Figure 1D). To further evaluate hepatocyte apoptosis in the liver, a TUNEL-based immunohistochemistry assay was performed. Consistently, livers from $\mathrm{HBx}$ - Tg mice exhibited a pronounced accumulation of TUNEL-positive cells compared with those from WT mice following I/R treatment (Figure 1E). These findings confirm that $\mathrm{HBx}-\mathrm{Tg}$ mice are more susceptible to oxidative stress-induced hepatocyte apoptosis.

To evaluate whether increased oxidative stress contribute to the pro-apoptotic effect of $\mathrm{HBx}$, mice were given antioxidant butylated hydroxyanisole (BHA)-containing $(0.7 \%)$ or control chow for 2 days and then challenged with liver I/R. Importantly, BHA administration not only restored the liver GSH content and GSH/ GSSG ratio and reduced DHE-stained cells in I/R-treated $\mathrm{HBx}-\mathrm{Tg}$ mice to a level similar to matched controls, but also effectively abrogated increased cell apoptosis in livers of I/R-challenged HBx-Tg mice (Figure $1 \mathrm{~B}, \mathrm{C}$ and 1D). Furthermore, histological analysis revealed that BHA treatment almost completely blocked appearance of TUNEL-positive hepatocytes in I/R-treated HBxTg mice (Figure 1E). Thus, HBx enhances oxidative 
A.
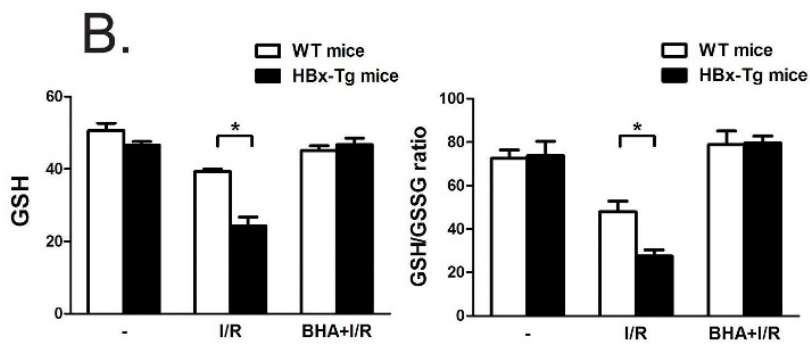

C.

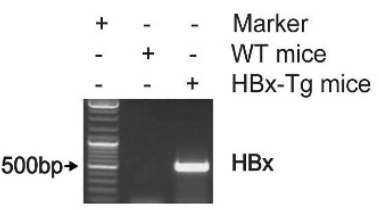

D.

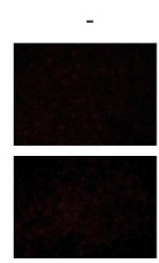

I/R

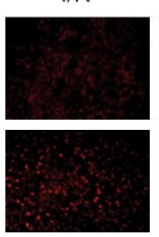

$\mathrm{BHA}+\mathrm{I} / \mathrm{R}$

E.
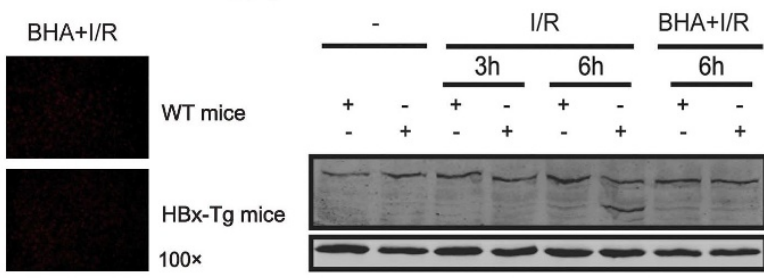

WT mice HBX-Tg mice

PARP

+ cleaved PARP

GAPDH
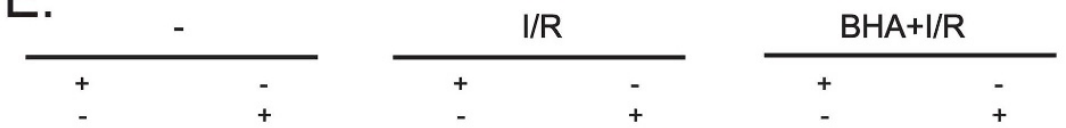

WT mice
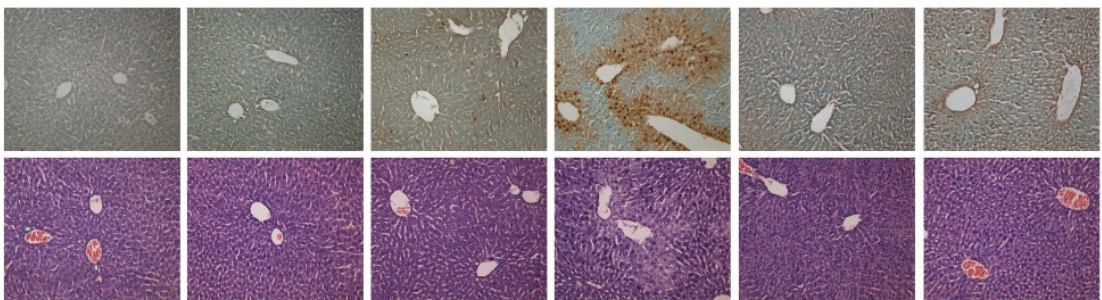

$\mathrm{HBx}-\mathrm{Tg}$ mice
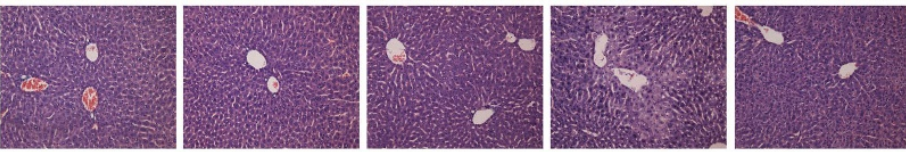

Figure $1 \mathrm{HBx}$-Tg mice exhibit an increased oxidative stress and susceptibility to liver ischemia-reperfusion challenge. (A) The transcript of $\mathrm{HBX}$ in livers from HBX-Tg or wide type (WT) mice was detected using RT-PCR. (B) Mice were given butylated hydroxyanisole (BHA)-containing $(0.7 \%)$ or control diet for 2 days and then subjected to $60 \mathrm{~min}$ of warm liver ischemia (see "Materials and Methods"), followed by $6 \mathrm{hr}$ of reperfusion before sacrificed. Total liver GSH content and GSH/GSSG ratio were determined. Values are mean \pm SD $(n=4)$. ${ }^{*}, p<0.05$. (C) Frozen liver sections from mice treated as in Fig. 1B were subjected to dihydroethidine (DHE) staining. Representative results are shown. Magnification, $\times 100$. (D) Livers from mice treated as in Fig. $1 B$ were homogenized and the protein levels of PARP and GAPDH were determined by Western blot assay. GAPDH was used as a loading control. (E) Liver sections from mice treated as in Fig. 1B were subjected to TUNEL and HE staining. Representative results are shown. Magnification, $\times 100$.

stress-induced cell death through a mechanism likely to depend on ROS accumulation.

\section{HBx enhances cellular ROS production and sensitizes hepatocytes to $\mathrm{H}_{2} \mathrm{O}_{2}$-induced apoptosis}

To further confirm the in vivo data, we employed $\mathrm{HBx}$ expressing stable HepG2 (HepG2-HBx) cells and empty vector (HepG2-con) counterparts as described previously [30]. Consistent with our in vivo results, $\mathrm{H}_{2} \mathrm{O}_{2}$ exposure resulted in an increase in ROS levels in HepG2-con cells, but under the same condition, much more ROS-positive cells were seen in $\mathrm{H}_{2} \mathrm{O}_{2}$-exposed HepG2-HBx cells than control cells (Figure 2A). To examine whether the effect of HBx on ROS accumulation reflects the events in HBVinfected cells, we compared the ROS levels in parental HepG2 cells with HepG2.2.15 cells that constitutively replicated $\mathrm{HBV}$ upon exposure to $\mathrm{H}_{2} \mathrm{O}_{2}$. Similarly, HepG2.2.15 cells also exhibited a greater percentage of ROS-positive cells than parental HepG2 cells (Figure 2A).

To explore the role of ROS in the mechanism of $\mathrm{HBx}$ sensitized cell apoptosis, cells were treated with $\mathrm{H}_{2} \mathrm{O}_{2}$ in concentrations from 100 to $400 \mu \mathrm{M}$. HBx-mediated cell death was found to increase after $\mathrm{H}_{2} \mathrm{O}_{2}$ exposure in a dose-dependent manner (Figure 2B). To evaluate the potential dose-effect relationship between $\mathrm{HBx}$ and apoptotic killing, a recombinant Myc-tagged $\mathrm{HBx}$-expressing adenoviral system was used as described previously [30]. As expected, adenovirus-mediated gene transfer of $\mathrm{HBx}$ dose-dependently increased the susceptibility of HepG2 cells toward $\mathrm{H}_{2} \mathrm{O}_{2}$-induced apoptosis (Figure $2 \mathrm{C}$ ).

Despite the evidence that apoptosis was apparent in the $\mathrm{HBx}$-expressing cells, it is not sufficient to reflect 


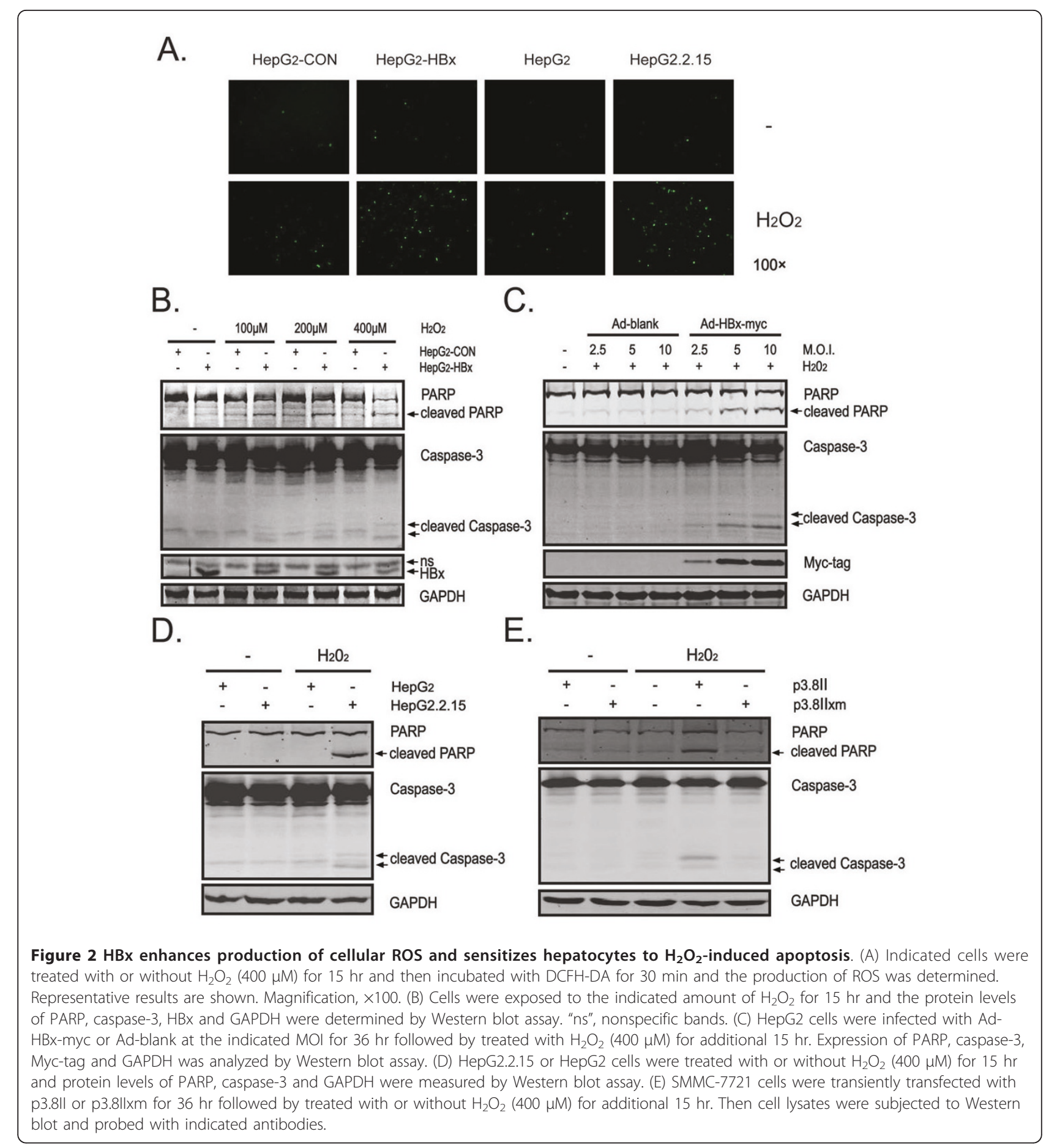

what really happens during HBV infection as the level of HBx expression is usually low in HBV-infected cells and tissues. Therefore, we examined the apoptotic susceptibility of HepG2.2.15 cells upon oxidative stress stimulation. Consistently, $\mathrm{H}_{2} \mathrm{O}_{2}$ treatment induced significant apoptotic killing in HepG2.2.15 cells as compared to control cells (Figure 2D), supporting an apoptosis- promoting activity of HBV under oxidative stress conditions. To further determine whether $\mathrm{HBx}$ is required for HBV-induced cell death, SMMC-7721 cells were transfected with the p3.8II plasmid containing the wild-type HBV genome or with p3.8IIxm, an HBx-mutated HBV genome and then challenged with $\mathrm{H}_{2} \mathrm{O}_{2}$ stress. Strikingly, p3.8II-transfected cells showed an increased 
susceptibility to $\mathrm{H}_{2} \mathrm{O}_{2}$-induced apoptosis (Figure 2E), whereas p3.8IIxm-transfected cells showed significant apoptosis resistance in response to $\mathrm{H}_{2} \mathrm{O}_{2}$ stimulation, indicating that $\mathrm{HBx}$ is essential for $\mathrm{HBV}$-induced apoptotic killing.

Together, these in vitro and in vivo data confirm that HBx enhances cellular ROS accumulation and triggers apoptosis under conditions of oxidative stress.

$\mathrm{HBx}$ decreases the expression of the anti-apoptotic Mcl-1 protein upon oxidative stress stimulation

Next, we attempted to investigate the molecular events responsible for $\mathrm{HBx}$-enhanced cell death upon exposure to oxidative stress. In view of the pivotal role that anti- apoptotic Bcl-2 family members play in mitochondrial integrity and hepatocyte survival $[18,19]$, we examined expression of three important anti-apoptotic Bcl-2 family proteins $(\mathrm{Bcl}-2, \mathrm{Mcl}-1$, and $\mathrm{Bcl}-\mathrm{xL})$ in response to $\mathrm{H}_{2} \mathrm{O}_{2}$. Consistent with a previous report [31], Bcl-2 protein was not detected in hepatoma cell lines examined (Figure 3). Interestingly, protein levels of Mcl-1 declined significantly in HepG2-HBx cells compared with those in HepG2-con cells after $\mathrm{H}_{2} \mathrm{O}_{2}$ treatment in a dosedependent manner, while $\mathrm{Bcl}-\mathrm{xL}$ protein levels revealed no substantial difference between HepG2-HBx and HepG2-con cells (Figure 3A). In addition, ectopic expression of $\mathrm{HBx}$ significantly reduced $\mathrm{Mcl}-1$ expression in HepG2 and Huh-7 cells, but had no major effect
A.
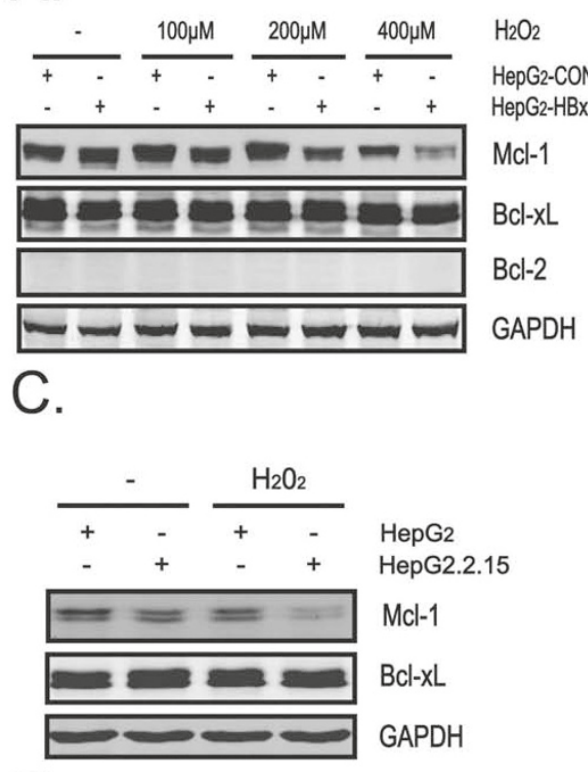

HepG2

HepG2.2.15

$\mathrm{Mcl}-1$

$\mathrm{Bcl}-\mathrm{xL}$

GAPDH

D.

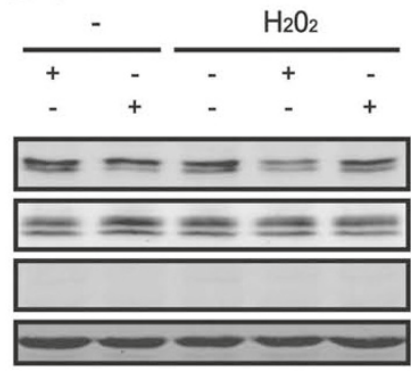

B.

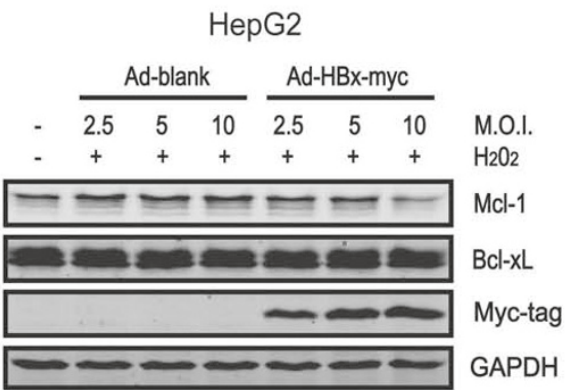

Huh-7

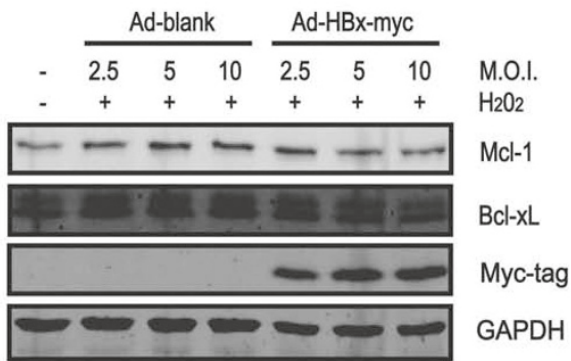

E.

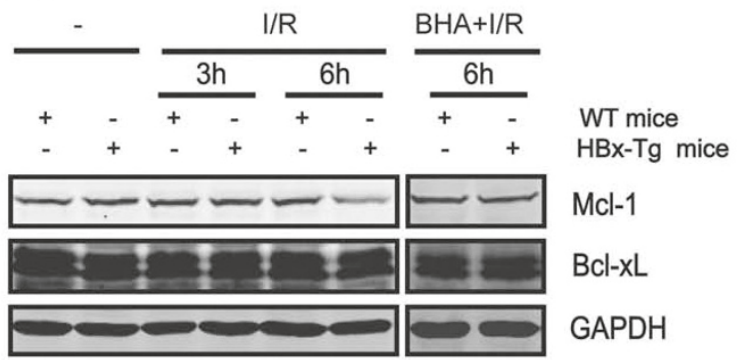

Figure $3 \mathrm{HBx}$ decreases the expression of the anti-apoptotic Mcl-1 protein upon oxidative stress stimulation. (A) Cells were exposed to the indicated amount of $\mathrm{H}_{2} \mathrm{O}_{2}$ for $15 \mathrm{hr}$ and expression of $\mathrm{Mcl}-1, \mathrm{BCl}-\mathrm{xL}, \mathrm{BCl}-2$ and GAPDH was analyzed by Western blot assay. (B) HepG2 or Huh-7 cells were infected with Ad-HBx-myc or Ad-blank at the indicated MOl for 36 hr followed by treated with $\mathrm{H}_{2} \mathrm{O}_{2}(400 \mu \mathrm{M})$ for additional 15 hr. Expression of Mcl-1, BCl-xL, Myc-tag and GAPDH was analyzed by Western blot assay. (C) Cells were treated with or without $\mathrm{H}_{2} \mathrm{O}_{2}(400 \mu \mathrm{M})$ for $15 \mathrm{hr}$ and indicated proteins were determined by Western blot assay. (D) SMMC-7721 cells were treated as in Fig. 2E and indicated proteins were determined by Western blot assay. (E) Livers from mice treated as in Fig. 1D were homogenized and protein levels of Mcl-1, BCl-xL and GAPDH were determined by Western blot assay. 
on Bcl-xL expression (Figure 3B). Furthermore, Mcl-1 expression decreased greatly in HBV-replicating HepG2.2.15 cells compared with that in parental HepG2 cells after treatment with $\mathrm{H}_{2} \mathrm{O}_{2}$ (Figure 3C), suggesting that HBV may have a similar effect on Mcl-1 expression as HBx does. Importantly, protein levels of Mcl-1 significantly reduced in p3.8II-transfected but not p3.8IIxmtransfected SMMC-7721 cells upon $\mathrm{H}_{2} \mathrm{O}_{2}$ exposure, suggesting that $\mathrm{HBx}$ is also essential for $\mathrm{HBV}$ to promote the loss of Mcl-1 protein (Figure 3D). To further confirm these in vitro findings, mice were challenged with liver I/R treatment and Mcl-1 expression in livers of $\mathrm{HBx}-\mathrm{Tg}$ and WT mice was determined by Western blot assay. As illustrated in Figure 3E, levels of Mcl-1 were also found to decrease in livers of I/R-challenged $\mathrm{HBx}$ Tg mice as compared to matched controls. Additionally, antioxidant BHA pretreatment abrogated the loss of Mcl-1 protein in livers of I/R-treated $\mathrm{HBx}-\mathrm{Tg}$ mice, suggesting that $\mathrm{HBx}$-mediated diminished expression of Mcl-1 under oxidative stress conditions is mainly ROS dependent. Collectively, $\mathrm{HBx}$ accelerates the loss of Mcl-1 protein in response to oxidative stress both in vitro and in vivo.

\section{Reduction of $\mathrm{Mcl}-1$ is involved in pro-apoptotic effect of $\mathrm{HBx}$ in response to oxidative stress}

To determine whether loss of Mcl-1 plays a role in $\mathrm{HBx}-$ mediated apoptotic killing under oxidative stress conditions, Mcl-1-expressing adenovirus (Ad-Mcl-1) and Mcl1-shRNA adenovirus (Ad-shMcl-1), which specific knockdown of Mcl-1 expression, were developed (Figure 4A). Importantly, enforced expression of Mcl-1 profoundly attenuated caspase- 3 activation and PARP cleavage in $\mathrm{H}_{2} \mathrm{O}_{2}$-treated HepG2-HBx cells compared with control cells (Figure 4B). Conversely, Adenovirus-mediated siRNA targeting Mcl-1 gene further exacerbated the activation of caspase- 3 and cleavage of PARP in HepG2-HBx cells upon $\mathrm{H}_{2} \mathrm{O}_{2}$ exposure (Figure 4C). Consistently, similar results were also obtained in HepG2.2.15 cells in which overexpression of Mcl-1 prevented the apoptotic cell death in $\mathrm{H}_{2} \mathrm{O}_{2}$-treated HepG2.2.15 cells, while knockdown of Mcl1 further increased the apoptotic susceptibility of HepG2.2.15 cells toward $\mathrm{H}_{2} \mathrm{O}_{2}$ stress (Figure 4D). Quantification of annexin-V-stained cells by FACS analysis further corroborated this finding: increased apoptosis in $\mathrm{H}_{2} \mathrm{O}_{2}$-treated HepG2.2.15 cells was significantly attenuated by Mcl-1 over-expression (Figure 5C).

To further evaluate the role of Mcl-1 down-regulation in $\mathrm{HBx}$-mediated cell death under oxidative stress conditions in vivo, $\mathrm{HBx}$-Tg mice were administered Mcl-1-expressing plasmid (p3×flag-Mcl-1) or control plasmid (p3×flag) by tail vein injection, and Mcl-1 expression was confirmed in livers from $\mathrm{p} 3 \times$ flag-Mcl-1-treated mice (Additional file 1 Figure S1). Three days later, mice were subjected to warm liver I/R challenge. As expected, TUNEL assay and serum ALT and AST examination showed that I/R challengeinduced liver injury in $\mathrm{HBx}-\mathrm{Tg}$ mice was greatly improved by $\mathrm{Mcl}-1$-expressing plasmid administration (Figure $4 \mathrm{E}$ and $4 \mathrm{~F}$ ). Thus, hepatocytes from $\mathrm{HBx}-\mathrm{Tg}$ mice are more susceptible to oxidative stress-induced apoptosis, at least in part, through accelerating the loss of Mcl-1 protein. These findings support the notion that reduction of Mcl-1 is required for pro-apoptotic effect of $\mathrm{HBx}$ under oxidative stress conditions.

\section{The caspase- 3 inhibitor prevents loss of $\mathrm{Mcl}-1$ in $\mathrm{HBX}$ - expressing cells upon $\mathrm{H}_{2} \mathrm{O}_{2}$ exposure}

It has been reported that caspase-3-mediated proteolysis may contribute to diminished expression of $\mathrm{Mcl}-1$ in some cell types [32-35]. We next investigated the effects of caspase- 3 inhibitor for its ability to modulate $\mathrm{HBx}$ enhanced Mcl-1 loss. Strikingly, caspase-3-specific inhibitor AC-DEVD-CHO not only prevented the activation of caspase- 3 and cleavage of PARP, but also attenuated the loss of Mcl-1 protein in $\mathrm{H}_{2} \mathrm{O}_{2}$-exposed HepG2-HBx cells in a dose-dependent manner (Figure 5A). Similarly, incubation of cell with AC-DEVD-CHO not only protected HepG2.2.15 cells against $\mathrm{H}_{2} \mathrm{O}_{2}$-induced apoptosis, but also inhibited the observed reduction in Mcl-1 expression in $\mathrm{H}_{2} \mathrm{O}_{2}$-treated HepG2.2.15 cells (Figure 5B and $5 \mathrm{C}$ ). The above experiments indicated that $\mathrm{HBx}$ may trigger caspase-3-mediated Mcl-1 turnover during $\mathrm{H}_{2} \mathrm{O}_{2}$ treatment because of the ability of the caspase- 3 inhibitor to prevent turnover. It was therefore important to investigate whether cleaved products of Mcl-1 could be detected in $\mathrm{HBx}$-expressing cells following $\mathrm{H}_{2} \mathrm{O}_{2}$ treatment and whether cleavage of $\mathrm{Mcl}-1$ could be prevented by caspase- 3 inhibitor. Following treatment with $\mathrm{H}_{2} \mathrm{O}_{2}$ for $12 \mathrm{hr}$, a band at approximately $28 \mathrm{kDa}$ was detected in HepG2-HBx cells using anti-Mcl-1 antibody, and this may be attributed to caspase-cleaved product of Mcl-1. Importantly, caspase-3 inhibitor AC-DEVD-CHO prevented the appearance of this band and restored protein levels of full-length Mcl-1 in $\mathrm{H}_{2} \mathrm{O}_{2}$-treated HepG2$\mathrm{HBx}$ cells, suggesting that $\mathrm{HBx}$ triggers loss of Mcl-1 protein mainly through caspase-3-mediated cleavage (Figure 5D). Of note, levels of this cleavage product decreased thereafter (data not shown), in agreement with some previous reports in some systems [34], indicating that the caspase-cleaved product of $\mathrm{Mcl}-1$ in HepG2-HBx cells in this scenario may be not stable. Thus, loss of Mcl-1 in HBx-expressing cells exposed to oxidative stress is mainly caspase- 3 dependent.

\section{Expression of $\mathrm{HBx}$ and $\mathrm{Mcl}-1$ is inversely correlated in HBV-related HCC tissues}

Malignant tumors, including $\mathrm{HCC}$, are frequently under persistent oxidative stress, and alterations in DNA repair 


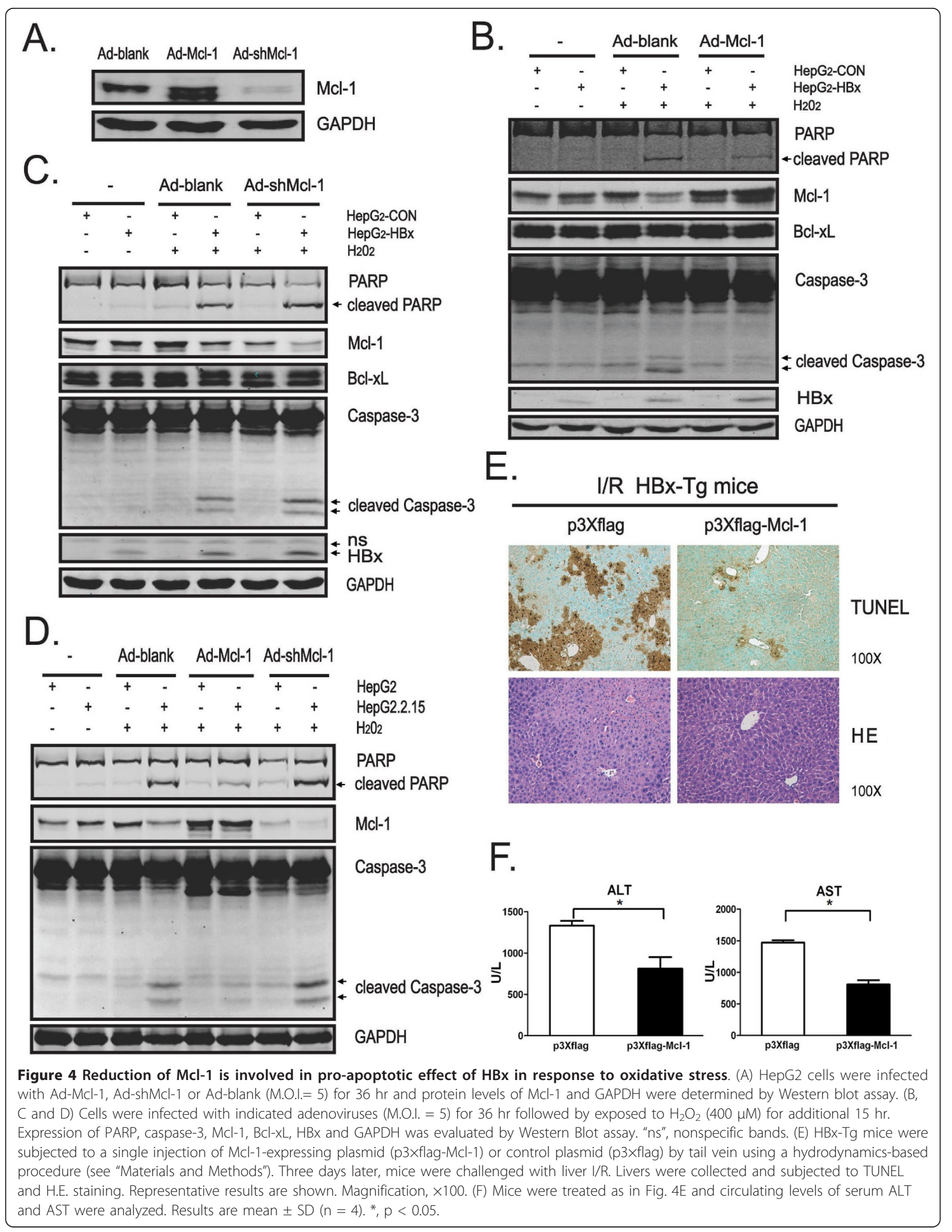


A.

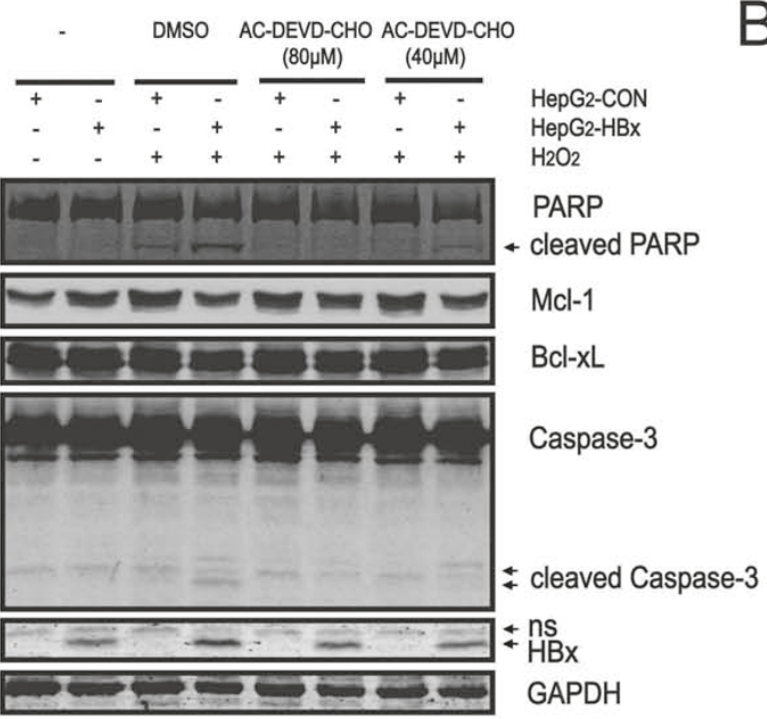

B.
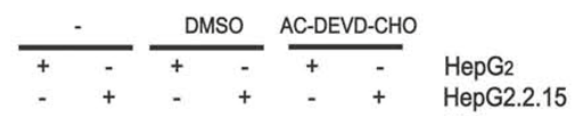

$-++++\mathrm{H}_{2} \mathrm{O}_{2}$

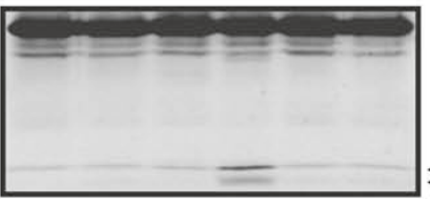

Caspase-3

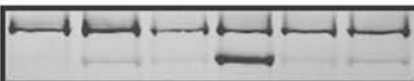
¥ cleaved Caspase-3

PARP
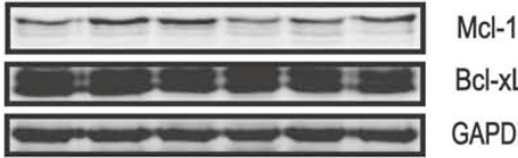

$\mathrm{Bcl}-\mathrm{XL}$

GAPDH
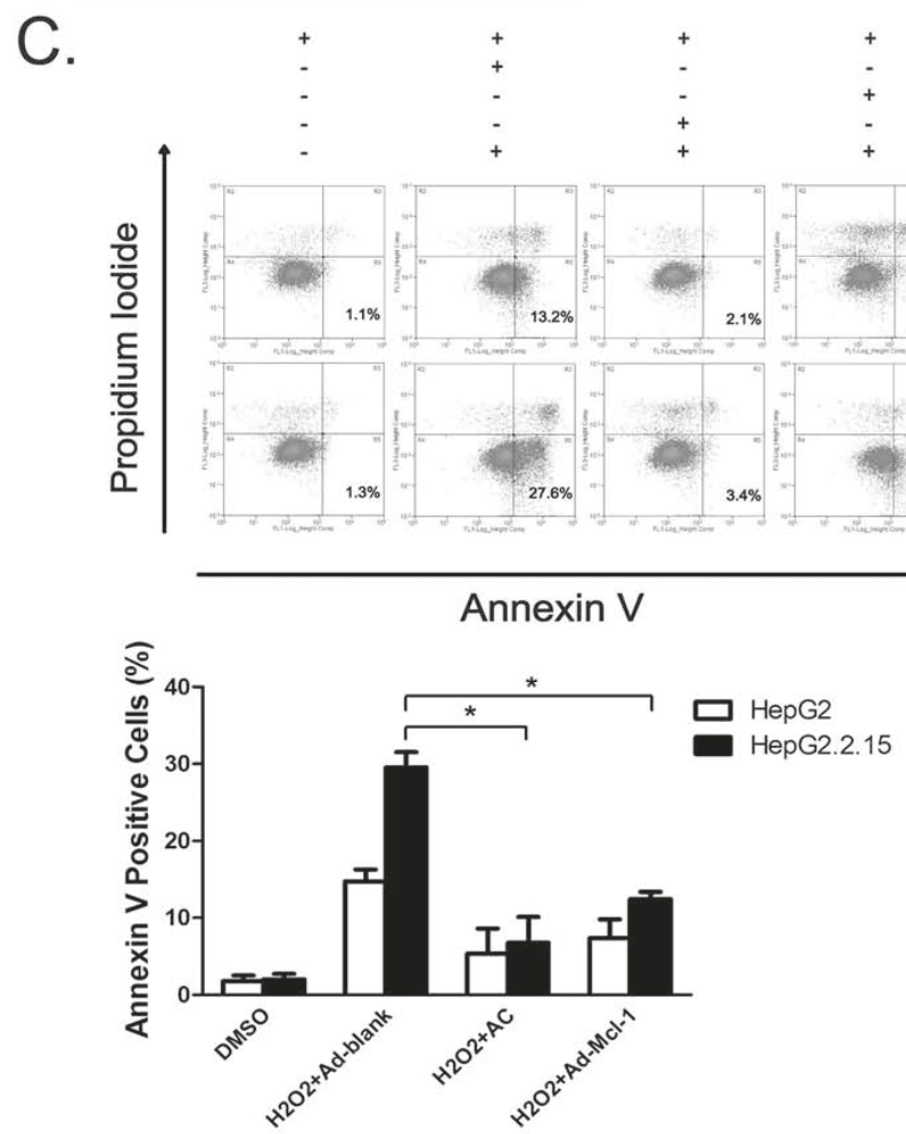

DMSO

Ad-blank

Ad-Mcl-1

AC-DEVD-CHO

$\mathrm{H}_{2} \mathrm{O}_{2}$

$\mathrm{HepG}_{2}$

HepG2.2.15

D.

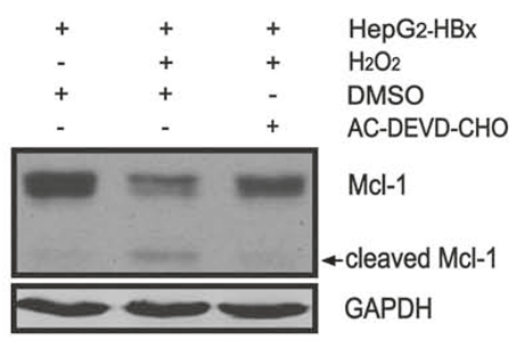

Figure 5 The caspase-3 inhibitor prevents loss of $\mathbf{M c l}-1$ in $\mathbf{H B x}$-expressing cells upon $\mathrm{H}_{2} \mathrm{O}_{2}$ exposure. (A and B) Cells were treated with or without indicated amount of AC-DEVD-CHO for $5 \mathrm{hr}$ followed by exposed to $\mathrm{H}_{2} \mathrm{O}_{2}(400 \mu \mathrm{M})$ for additional $15 \mathrm{hr}$. Expression of PARP,

caspase-3, Mcl-1, BCl-xL, HBx and GAPDH was determined by Western Blot assay. "ns", nonspecific bands. (C) Cells were infected with indicated adenoviruses (M.O.I. $=5)$ for $36 \mathrm{hr}$ or treated with DMSO or AC-DEVD-CHO $(80 \mu \mathrm{M})$ for $5 \mathrm{hr}$ followed by exposed to $\mathrm{H}_{2} \mathrm{O}_{2}(400 \mu \mathrm{M})$ for additional $15 \mathrm{hr}$. The extent of apoptosis was evaluated by FACS analysis. Representative results are shown. Plots (lower panel) are mean \pm SD of data from three independent experiments. *, p < 0.05. "AC", AC-DEVD-CHO. (D) Cells were treated with DMSO or AC-DEVD-CHO (80 $\mu$ M) for 5 hr followed by exposed to $\mathrm{H}_{2} \mathrm{O}_{2}(400 \mu \mathrm{M})$ for additional $12 \mathrm{hr}$. Expression of Mcl-1 was determined by Western Blot assay. A band at about $28 \mathrm{kDa}$ indicates the cleaved form of $\mathrm{Mcl}-1$. 
enzymes and antioxidant enzymes are considered as indicators of oxidative damage [36,37]. To evaluate the potential relationship between $\mathrm{HBx}$ and oxidative stress in HBV-related HCC tissues, expression of HBx, DNA repair enzyme human MutT homolog 1 (hMTH1) and antioxidant enzyme manganese superoxide dismutase (MnSOD) was analyzed in HBV-positive HCC tissues. As illustrated in Figure 6A, a positive correlation between $\mathrm{HBx}$ and hMTH1 mRNA expression was observed in $22 \mathrm{HCC}$ samples $(\mathrm{r}=0.38, \mathrm{p}=0.039)$. In addition, $\mathrm{HBx}$ mRNA expression was also significantly correlated to MnSOD mRNA expression in these HCC samples $(r=0.46, p=0.015)$ (Figure $6 \mathrm{~B})$. These results suggest that there may be a correlation between $\mathrm{HBx}$ expression and the extent of oxidative damage in HBVpositive $\mathrm{HCC}$ tissues.

To further examine the relationship between $\mathrm{HBx}$ and anti-apoptotic Bcl-2 family members in HBV-related HCCs, protein levels of Mcl-1 and Bcl-xL in HBV-positive $\mathrm{HCC}$ tissues were evaluated by Western blot analysis (Figure 6C). Since HBx protein was hardly detectable in

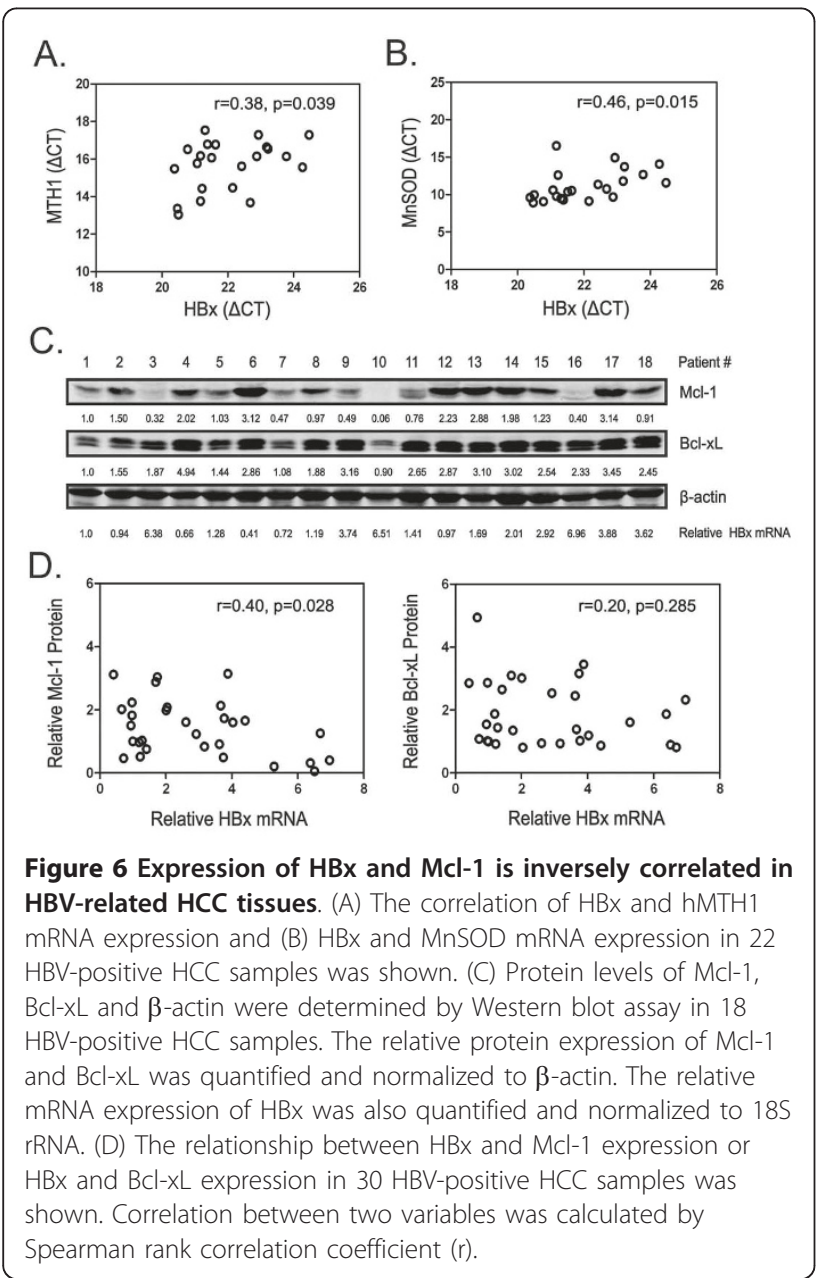

HCC tissues, HBx expression was determined by its mRNA levels. As expected, HBx mRNA expression was found to be inversely correlated with Mcl-1 protein expression in $30 \mathrm{HCC}$ samples $(\mathrm{r}=0.40, \mathrm{p}=0.028)$ However, no correlation was observed between $\mathrm{HBx}$ and $\mathrm{Bcl}-$ $x L$ expression $(r=0.20, p=0.285)$ (Figure 6D). Taken together, these histological observations, along with the above findings, suggest a potential pathophysiological role of Mcl-1 in HBV-associated hepatocarcinogenesis.

\section{Discussion}

Persistent oxidative stress has been suggested to be a major contributor to the development of HCC as it can exert multiple pro-tumorigenic effects, including altered gene expression [38], epigenetic modulations [37], enhanced hepatocyte death and IL-1 $\alpha$ release [29], genomic instability [39] as well as higher DNA mutation rates [40]. Given the critical role of $\mathrm{HBx}$ in the pathogenesis of HBV-related liver cancer [1,2] and Mcl-1 in liver homeostasis $[25,26,41]$, the purpose of this study was to determine whether the apoptotic susceptibility of hepatocytes under oxidative stress conditions could be disturbed by $\mathrm{HBx}$ and the potential role of Mcl-1 in this process.

In the present study, the concentration of $\mathrm{H}_{2} \mathrm{O}_{2}$ we used did not induce apparent apoptosis in control hepatocytes, while it did trigger significant apoptotic killing in HBx-expressing hepatocytes. Consistently, no major injury was detected in WT control mice following liver I/R challenge, while severe liver cell death were observed in $\mathrm{HBx}-\mathrm{Tg}$ mice receiving the same treatment. Furthermore, HBV-replicating HepG2.2.15 cells and SMMC7721 cells transfected with the wild-type, but not $\mathrm{HBx}-$ mutated, HBV genome unanimously exhibited increased apoptotic susceptibility to $\mathrm{H}_{2} \mathrm{O}_{2}$ stress. These in vitro and in vivo data clearly demonstrated that HBx expression sensitized hepatocytes to oxidative stress-mediated cell killing. Our findings agree with the majority results of previous observations which showed that $\mathrm{HBx}$ increases susceptibility of hepatocytes to a variety of apoptotic stimuli [7-12], although there are opposite data about the effects of $\mathrm{HBx}$ protein on apoptotic signals $[2,42]$. The discrepant activity of HBx on apoptosis may result from the different stages of natural HBV infection. It is possible, as proposed by Arbuthnot $\mathrm{P}$ and his colleagues [43], that $\mathrm{HBx}$ inhibits apoptosis at early stage during hepatocyte infection in order to facilitate HBV replication, while promotes apoptosis at later stage to accelerate virus spread.

Recent work showed that HBx mainly localizes in the mitochondria, disturbs mitochondrial membrane potential and subsequently increases ROS production, suggesting that HBx has an ability to activate mitochondria-dependent apoptosis. Given the critical role that anti-apoptotic 
Bcl-2 family proteins play in liver homeostasis and apoptosis control $[18,19]$, we went further to examine the expression of anti-apoptotic Bcl-2 members. Bcl-xL and Mcl-1 have been identified as major anti-apoptotic $\mathrm{Bcl}-2$ proteins in the liver for previous studies revealed that Bcl-2 is not generally expressed in human hepatocytes and hepatoma cell lines [31]. Both of these proteins play a crucial role for the maintenance of mitochondrial membrane integrity. They mainly localize at the outer membrane of mitochondria, prevent the oligomerization and the activation of multidomain pro-apoptotic proteins Bax and Bak [44,45]. In addition, they can also inhibit apoptosis by sequestering pro-apoptotic BH3-only proteins such as Bid, Bim or Puma [46]. Interestingly, however, only protein levels of Mcl-1 were found to decrease significantly in $\mathrm{HBx}$-expressing cell lines and livers of $\mathrm{HBx}-\mathrm{Tg}$ mice upon oxidative stress stimulation, while no major changes in Bcl-xL levels were observed. Consistently, analysis from clinical samples also revealed an inverse correlation between the expression of $\mathrm{HBx}$ and $\mathrm{Mcl}-1$, but not $\mathrm{Bcl}-\mathrm{xL}$, in HBV-related $\mathrm{HCC}$ tissues. Thus, these results argue against the involvement of $\mathrm{Bcl}-\mathrm{xL}$ in $\mathrm{HBx}$-mediated cell killing in response to oxidative stress and suggest that different anti-apoptotic Bcl-2 members may not functionally equivalent under certain conditions $[46,47]$. Furthermore, similar results were also obtained in HepG2.2.15 cells as well as p3.8II-transfected but not p3.8IIxm-transfected SMMC-7721 cells. Consistent with a previous report [48], we also observed a mild increase in $\mathrm{Mcl}-1$ protein levels in unstimulated HepG2-HBx cells compared with those in HepG2-con cells, and this may be due to the transactivation effects of $\mathrm{HBx}$. Nevertheless, upon $\mathrm{H}_{2} \mathrm{O}_{2}$ exposure, levels of Mcl-1 declined significantly in HepG2-HBx cells as compared to matched controls, indicating that rapid loss of this highly regulated protein may be involved in $\mathrm{HBx}$-mediated cell killing. Indeed, enforced expression of $\mathrm{Mcl}-1$ provided long-term protection against $\mathrm{HBx}$-induced apoptosis. Conversely, specific knockdown of Mcl-1 expression further exacerbated $\mathrm{HBx}$-induced apoptosis. It should be noted that the protection effect of Mcl-1 over-expression was relatively weaker than that of caspase- 3 inhibition, indicating that down-regulation of Mcl-1 may not be the exclusive pathway that mediates the pro-apoptotic activity of HBx.

Ahmad KA and colleague have demonstrated that Bax plays an important role in $\mathrm{H}_{2} \mathrm{O}_{2}$-induced apoptosis via mitochondrial translocation [49], meanwhile Mcl-1 has been shown to interact with Bak and prevent its translocation to the mitochondria $[44,45]$. We therefore examined the expression and mitochondrial translocation of $\mathrm{Bax} / \mathrm{Bak}$ in our system. Although $\mathrm{H}_{2} \mathrm{O}_{2}$ did trigger the translocation of Bax/Bak from the cytosol to the mitochondria, a reduced expression of Bax/Bak was observed in both the whole cell lysates and their mitochondria fractions of $\mathrm{HBx}$-expressing cells as compared to matched control cells (Additional file 1 Figure S2), which appears to be inconsistent with the previous report [49]. Nevertheless, we speculated that, after $15 \mathrm{hr}$ of treatment with $\mathrm{H}_{2} \mathrm{O}_{2}, \mathrm{HBx}$-expressing cells may undergo relatively late-stage apoptosis, which may lead to protease hydrolysis of Bax/Bak or trigger some potential mechanisms to dysregulate their expression. These observations are in agreement with an earlier study [50]. Moreover, the cleavage of Bax was also detected under this condition (data not shown). As we did not examine the expression and mitochondrial translocation of Bax/ Bak at earlier intervals, it is unlikely to rule out the possible involvement of Bax or Bak in HBx-enhanced cell death, yet, our findings strongly support the notion that Mcl-1 plays a functional role in $\mathrm{HBx}$-mediated apoptotic killing under oxidative stress conditions.

Expression of Mcl-1 is tightly controlled through diverse signaling pathways. Results of the present study identified the association of $\mathrm{Mcl}-1$ down-regulation with caspase activation, as caspase-3 inhibitor AC-DEVD$\mathrm{CHO}$ not only blocked $\mathrm{HBx}$-mediated apoptosis but also significantly attenuated the observed reduction of Mcl-1 expression in ROS-exposed HBx-expressing cells. These findings are consistent with our previous study, which demonstrated that $\mathrm{HBx}$ protein renders hepatocytes susceptible to chemotherapeutic agent cisplatin through stimulating oxidative stress-dependent caspase-3-mediated degradation of Mcl-1 [30]. Moreover, in this study, we further showed that $\mathrm{HBx}$ actually has the ability to sensitize hepatocytes to oxidative signals per se-induced apoptosis, and that this pro-apoptotic effect of $\mathrm{HBx}$ was also mediated through accelerating caspase-3-dependent loss of Mcl-1 protein. Furthermore, we also detected a caspase-cleaved product of $\mathrm{Mcl}-1$ in $\mathrm{H}_{2} \mathrm{O}_{2}$-treated HepG2-HBx cells, as this cleavage of Mcl-1 could be prevented by caspase- 3 inhibitor. Given these observations, we propose that caspase-3-mediated degradation of Mcl-1 may represent a common mechanism during pro-oxidant stimuli-induced apoptosis in HBx-expressing cells.

Of note, although caspase-3 inhibitor greatly prevented Mcl-1 loss in $\mathrm{H}_{2} \mathrm{O}_{2}$-treated HepG2-HBx cells, it did not completely restore its protein levels as compared to unstimulated HepG2-HBx cells (Figure 5D), indicating that other mechanism may also contribute to reduce Mcl-1 expression. Inoshita $S$ and coworkers [28] reported that short-term exposure (1 3 hr) of HEK293 and PAE cells to hydrogen peroxide results in JNK activation, which leads to apoptosis through phosphorylation and inactivation of $\mathrm{Mcl}-1$, while they did not explore the effect of long-term $\mathrm{H}_{2} \mathrm{O}_{2}$ exposure on Mcl-1 expression. In the present study, we noticed that over $12 \mathrm{hr}$ exposure of $\mathrm{HBx}$-expressing hepatocytes to $\mathrm{H}_{2} \mathrm{O}_{2}$ 
caused a significant decrease in cellular Mcl-1 levels, and we also observed sustained activation of JNK in this setting (data not shown). As the ability of HBx to activate JNK pathway has been reported by several groups [51,52], future study should be warranted to determine the possible involvement of JNK signaling in $\mathrm{HBx}$-triggered loss of Mcl-1 protein.

The observation that caspase- 3 inhibitor prevented the loss of Mcl-1 protein in $\mathrm{H}_{2} \mathrm{O}_{2}$-exposed $\mathrm{HBx}$-expressing cells indicates that although Mcl-1 mainly functions upstream of caspases, the major regulation of Mcl-1 by $\mathrm{HBx}$ following $\mathrm{H}_{2} \mathrm{O}_{2}$ treatment lies downstream of caspase-3. Thus, the reduction of full-length Mcl-1 protein levels due to caspase-3-mediated proteolysis represents a secondary rather than a primary event in the induction of cell death. We suppose that, under oxidative stress conditions, $\mathrm{HBx}$ may activate caspase- 3 signaling through a Mcl-1-independent mechanism, and activated caspase-3 triggers down-regulation of full-length Mcl-1 protein through proteolysis, thus resulting in the impairment of the inhibitory effect of this anti-apoptotic molecule on mitochondria-dependent apoptosis and subsequent caspase-3 activation. As a result, caspase-3 cascade is further activated in a positive feedback loop, allowing the irreversible commitment to cell death. Recently, caspase-mediated proteolysis of Mcl-1 has been confirmed by several independent groups [32-35], however, it remains unclear whether the caspase- 3 cleavage sites in $\mathrm{Mcl}-1$ protein in $\mathrm{HBx}$-expressing hepatocytes are still the same (Asp127 and Asp157) as reported previously [33], future studies based on sitedirected point mutations and sequence analysis would help to address this issue. Moreover, it will be important to elucidate which signaling pathway is responsible for $\mathrm{HBx}$-mediated caspase- 3 activation under oxidative stress conditions.

In line with several previous reports [9,53], a slightly increased level of oxidative stress was observed both in unstimulated HepG2-HBx and HepG2.2.15 cells as well as livers of HBx-Tg mice as compared to their respective controls. Strikingly, upon moderate oxidative stress stimulation, HBx greatly enhanced the extent of oxidative stress, which was accompanied by a significant increase in the rate of apoptosis in HBx-expressing cells both in vitro and in vivo. Thus, $\mathrm{HBx}$ protein and oxidative signals may synergize to augment cellular ROS accumulation up to a deleterious level resulting in apparent liver injury. Antioxidant treatment effectively abrogated the loss of Mcl-1 protein and cell death in $\mathrm{HBx}$-expressing cells, suggesting that pro-apoptotic effect of $\mathrm{HBx}$ under oxidative stress conditions is mainly ROS dependent. The fact that HBx-mediated cell killing was not apparent until moderate pro-oxidant stimuli were administrated indicates that a certain threshold of
ROS level would be required to trigger apoptosis and that $\mathrm{HBx}$ itself may not be sufficient to initiate apoptotic event, but rather function as an apoptosis inducer under stress conditions $[9,47]$. Thus, results of the present work highlighted the importance of ROS accumulation in the pro-apoptotic activity of $\mathrm{HBx}$, nevertheless, the exact mechanism by which HBx significantly stimulates cellular ROS production remains to be elucidated.

Controlled hepatocyte apoptosis is essential for liver homeostasis. However, uncontrolled apoptosis can induce compensatory proliferation of hepatocytes $[25,26]$. Although the ideas that increased hepatocyte apoptosis can cause liver cancer are seemingly inconsistent with the known phenomenon of apoptosis resistance of pre-malignant and malignant hepatocytes, uncontrolled hepatocyte apoptosis can lead to compensatory hepatocyte proliferation and cause HCC in animal model [26]. It is known that chronic viral hepatitis is characterized not only by inflammation, but also by an increased rate of apoptosis and elevated caspase activities to preserve homeostasis after tissue damage [54]. Therefore, it is likely that, as has been suggested by others [7], enhanced hepatocyte death triggered by $\mathrm{HBx}$ may promote the induction of liver cell growth factors, which in turn enhance compensatory hepatocyte proliferation, not only creating a larger reservoir of new uninfected hepatocytes to propagate the viral infection but also contributing to the development of HCC.

Mcl-1 was found to be highly expressed in human $\mathrm{HCC}$, and has been implicated in the apoptosis resistance of HCC cells [23,24]. Thus, Mcl- 1 seemingly plays a contradictory role in hepatocarcinogenesis. However, the role that Mcl-1 plays in HCC promotion and progression may depend on the milieu. It has long been known that chronic inflammation and tumor tissues are frequently under oxidative stress $[14,55,56]$. Hence, it is possible that, on one side, acceleration of Mcl-1 loss in HBV-infected hepatocytes under moderate or sublethal oxidative stress conditions may result in a pro-apoptotic environment provoking compensatory proliferation, finally giving rise to the outgrowth of the neoplastic cell population and contributing to the initiation of liver cancer [26]. On the other side, malignant hepatocytes that over expresses Mcl-1 can be selected during tumor progression and eventually confer resistance of $\mathrm{HCC}$ cells to apoptosis triggers. Our findings are also in agreement with a tumor promoting effect of a pro-oxidant intracellular milieu. For example, Clément MV and his groups demonstrated that overexpression of Bcl-2 increases intracellular $\mathrm{O}_{2}{ }^{-}$and inhibits apoptotic acidification and cell death, while decrease in intracellular superoxide sensitizes $\mathrm{Bcl}$-2-overexpressing tumor cells to apoptotic killing [57]. Consistently, Pervaiz, S and coworkers reported that GTP-binding protein Rac 
induces production of superoxide, thereby inhibiting tumor cell response to apoptosis, conversely, inhibition of the Rac pathway causes a decrease in superoxide anion concentration, resulting in a significant increase in tumor cell sensitivity to apoptosis [58].

\section{Conclusions}

In conclusion, we provide both in vitro and in vivo evidence that HBx has the ability to enhance the susceptibility of hepatocytes toward oxidative stress-induced apoptotic killing by accelerating the loss of Mcl-1 protein, which is mainly caspase- 3 dependent. Therefore, tissue microenvironments generating ROS such as chronic inflammation and injury may aggravate the pathogenesis of HBV-related liver disease by provoking cell death.

\section{Materials and methods Antibodies and Reagents}

The primary antibodies specific for Mcl-1 (S-19 and K20), Bax (N-20) and Bak (N-20) were purchased from Santa Cruz Biotechnology. Antibodies for Bcl-xL, Bcl-2, Caspase-3, PARP, GAPDH and Myc-tag were from Cell Signaling Technology (CST). Purified anti-Mcl-1 antibody was from Biolegend. Rabbit polyclonal anti-HBx antibody was generated in our laboratory. peroxide hydrogen $\left(\mathrm{H}_{2} \mathrm{O}_{2}\right)$, butylated hydroxyanisole (BHA), 4',6'Diamidino-2-phenylindole (DAPI) were from SigmaAldrich; AC-DEVD-CHO were from Calbiochem.

\section{Cell Lines and Cell Culture}

HepG2, Huh-7 and HEK293A cell lines were obtained from American Type Culture Collection (Manassas, VA). SMMC-7721 and HepG2.2.15 cell lines were from the Cell Research Institute of Chinese Academy of Sciences (Shanghai, China). Cells were maintained at $37^{\circ}$ $\mathrm{C}$ in a humidified incubator containing $5 \% \mathrm{CO}_{2}$ in Dulbecco's modified Eagle's medium supplemented with $10 \%$ heat-inactivated fetal bovine serum and passed every 2-3 d to maintain logarithmic growth.

\section{Plasmids and Recombinant Adenovirus Preparation}

The Myc-tagged full-length HBx plasmid (pcDNA3.1$\mathrm{HBx}$-myc) was constructed by inserting a PCR-amplified full-length $\mathrm{HBx}$ fragment into the EcoRI/KpnI sites of pcDNATM3.1/myc-His(-)A (Invitrogen), using the primers, forward, 5'-CGGAATT-CATGGCTGCTAGG CTGTGCTG-3' and reverse, 5'-GGGGTACCGGCAGAGGTGAAAAAGTTGC-3'. The Mcl-1-expressing plasmid (p3×flag-Mcl-1) was generously provided by Prof. Wu Mian (University of Science and Technology of China, Hefei, China). The control (Ad-blank), Myctagged HBx-expressing (Ad-HBx-myc), Mcl-1-expressing (Ad-Mcl-1) and Ad-shMcl-1 (harboring Mcl-1-small hairpin RNA, Mcl-1-shRNA) recombinant adenoviruses were generated as described previously [30]. The primers were as follows: pAd-HBx-myc, forward, 5'-CGGAATTCATGGCTGCTAGGCTGTGCTG-3'; reverse, 5'GAAGATCTAAGCT-GGAGACCGTTTAAAC-3'; pAdMcl-1, forward, 5'-GGAATTCATGTTTGGC-CTCAAA AGAAACGCGG-3'; reverse, 5'-CGGGATCCGTCAAC TATTGCACTT-ACAGTAAGG-3'. Mcl-1-shRNA was generated using the pSUPER RNAi System ${ }^{\mathrm{TM}}$ (Promega). The Mcl-1 siRNA sequence used was included in the following sense and antisense oligonucleotides: 5'GATCCCCCGGGACTGGCTAGTTAAACTTC-AAGA GAGTTTAACTAGCCAGTCCCGTTTTTA-3' and 5'AGCTTAAAAAC-GGGACTGGCTAGTTAAACTCT CTTGAAGTTTAACTAGCCAGTCCCGGGG-3'. Sense and antisense strands were annealed and ligated into the linearized pSUPER.neo+GFP Vector following the manufacturer's directions. All the constructs were confirmed by DNA sequencing and Western blot analysis. The recombinant adenovirus was generated in HEK293A cells by homologous recombination system. Adenovirus was purified using Adeno- $\mathrm{X}^{\mathrm{TM}}$ Virus Purification Kit (Clontech Laboratories). The titer of the virus was determined using Adeno-X ${ }^{\mathrm{TM}}$ Rapid Titer Kit (Clontech Laboratories) following the manufacturer's instructions.

\section{Transient transfection}

SMMC-7721 cells were transiently transfected using PEI (Polyplus; AFAQ) as described previously [59].The plasmid p3.8II containing the wild-type HBV genome and p3.8IIXm consisting of an $\mathrm{HBx}$-mutated HBV genome were kindly provided by Prof. Zhao Mujun (Institute of Biochemistry and Cell Biology, Shanghai Institutes for Biological Sciences, Chinese Academy of Sciences, Shanghai, China) [3].

\section{Semi-Quantitative and Real-Time Reverse Transcription- PCR}

Total RNAs were isolated from cells or HCC samples using TRIzol Reagent (Invitrogen) following the manufacturer's instructions. The complementary DNA template was prepared using random primers and Moloney Murine Leukemia Virus reverse transcriptase (Promega) according to the manufacturer's protocol. After the reverse transcription reaction, the complementary DNA template was either semi-quantitated by reverse transcription-PCR (RT-PCR) or quantitated using real-time PCR technology. The primers used in this study are as follows: HBx (AY310322) forward, 5'-ATGGCTGC TAGGCTGTGCTG-3'; reverse, 5'-GGCAGAGGTGAAAAAGTTGC-3'; hMTH1 (AK026631) forward, 5'-AGC CTCAGCGAGTTCT-CCTG-3'; reverse, 5'-GATCTGG CCCACCTTGTGC-3'; hMnSOD (Y00472) forward, 5'GAGATGTTACAGCCCAGATAGC-3'; reverse, 5'- 
AATCCCCAGCAGTGGAA-TAAGG-3'; 18sRNA (NR_003286) forward, 5'-CGGCTACCACATCCAAGGAA-3'; reverse, 5'-GCTGGAATTACCGCGGCT-3'. 18srRNA was used as a control. Each sample was tested in duplicate.

\section{Western Blot Analysis}

Western blotting was performed as described previously [60]. Briefly, whole-cell extracts or tumor specimens were prepared in lysis buffer [Tris- $\mathrm{HCl}(20 \mathrm{mM}), \mathrm{pH}$ $7.4, \mathrm{NaCl}(150 \mathrm{mM})$, glycerol (10\%), Nonidet P-40 (0.2\%), EDTA (1 mM), EGTA $(1 \mathrm{mM})$, PMSF $(1 \mathrm{mM})$, $\mathrm{NaF}(10 \mathrm{mM})$, aprotinin $(5 \mathrm{mg} / \mathrm{ml})$, leupeptin $(20 \mathrm{mM})$, and sodium orthovanadate $(1 \mathrm{mM})]$ and centrifuged at $12,000 \mathrm{~g}$ for $15 \mathrm{~min}$. Protein concentrations were measured using the BCA assay. Immunoblotting was performed using specific primary antibodies and immunocomplexes were incubated with the appropriate horseradish-peroxidase-conjugated secondary antibodies or fluorescein-conjugated secondary antibody, and then detected using the ECL kit (Santa Cruz Biotech) or Odyssey fluorescence scanner (Li-Cor, Lincoln, NE).

\section{Reactive Oxygen Species and Glutathione Measurement}

Production of ROS was measured with the fluorogenic dye 2', 7'-dichloro-fluorescin diacetate (DCFH-DA), a cell permeant compound, using Reactive Oxygen Species Assay Kit (Invitrogen). Briefly, Cells were preincubated with DCFH-DA $(10 \mu \mathrm{M})$ for $30 \mathrm{~min}$ at $37^{\circ} \mathrm{C}$. After the extracellular dye was removed, the cells were washed 3 times and incubated with serum-free DMEM. Subsequently, fluorescence was measured at $488 \mathrm{~nm}$ excitation and $525 \mathrm{~nm}$ emission using a fluorescence microscope (Olympus). Total liver glutathione (GSH) content were determined by a commercial kit (Jiancheng, Nanjing, China) according to the manufacturer's protocol. GSH and GSSG Levels were measured using a GSH and GSSG Assay Kit (Beyotime, China). Liver in situ ROS production were determined by staining frozen liver sections with dihydroethidine (DHE) (Invitrogen), whose oxidation leads to the fluorescent derivative ethidine [29].

\section{Apoptosis Analysis}

For apoptosis analysis, cells were seeded into 6-well plates with $5 \times 10^{5}$ cells/well and incubated overnight followed by treatment with or without $\mathrm{H}_{2} \mathrm{O}_{2}$. The extent of apoptosis was determined by FACS analysis (Beckman Coulter) using Annexin V Apoptosis Detection Kit (Invitrogen). Apoptotic cells in the liver were detected by terminal deoxynucleotidyl transferase dUTP nick end labeling (TUNEL) staining using In Situ Apoptosis Detection Kit (Calbiochem), and the nucleus was counterstained with methyl green.

\section{Preparation of cytosolic and mitochondria fractions}

Preparation of cytosolic and mitochondria fractions was achieved using a commercially available cytosol/mitochondria fractionation kit according to the manufacturer's protocol (Beyotime, China). Briefly, $1 \times 10^{7}$ cells were washed with ice-chilled PBS at 1,200 g. Cell pellets were resuspended in $500 \mu \mathrm{L}$ of extraction buffer and incubated at $4^{\circ} \mathrm{C}$ for 20 minutes, followed by homogenization. The homogenate was centrifuged at $1,000 \mathrm{~g}$ for 10 minutes at $4^{\circ} \mathrm{C}$. The supernatant was additionally centrifuged at 3,500 g for 10 minutes (fraction enriched with intact mitochondria). The supernatant from the last centrifugation was used as the cytosolic fraction and the final pellet represents a more purified mitochondrial fraction.

\section{Liver Ischemia}

HBx transgenic mice were kindly provided by Prof. Yang Xiao (Genetic Laboratory of Development and Diseases, Institute of Biotechnology, Beijing, China). The identification of $\mathrm{HBx}$ transgenic mice was performed as described previously [61]. A nonlethal model of segmental $(70 \%)$ hepatic warm ischemia was used. All structures in the portal triad (hepatic artery, portal vein, bile duct) to the left and median liver lobes were occluded with a microvascular clamp for $60 \mathrm{~min}$; reperfusion was initiated by removal of the clamp. At the end of the observation period, mice were sacrificed by cervical dislocation.

\section{In Vivo Gene Expression Experiments}

Plasmid DNA was administered into mice by a hydrodynamic-based gene transfer technique via rapid injection of a large volume of DNA solution through the tail vein, as described elsewhere [62]. Briefly, $20 \mu \mathrm{g}$ Mcl-1-expressing plasmid ( $3 \times$ flag-Mcl-1) or control plasmid (p3×flag) was diluted in $1.8 \mathrm{ml}$ of saline and injected by tail vein into the circulation within 5 to $10 \mathrm{~s}$. Three days later, mice were treated with $60 \mathrm{~min}$ of warm liver ischemia followed by $6 \mathrm{hr}$ of reperfusion challenge before sacrificed. Part of the liver was processed for TUNEL-based immunohistochemistry and hematoxylin and eosin (HE) staining and the remaining liver was immediately frozen in liquid nitrogen and stored at $-80^{\circ}$ $\mathrm{C}$ for tissue lysate preparation. All animals received human care according to the criteria outlined in the Guide for the Care and Use of Laboratory Animals [63].

\section{Aminotransferase Levels}

About $100 \mu \mathrm{l}$ of blood was collected from the tail vein. Alanine aminotransferase (ALT) and aspartate aminotransferase (AST) were measured in the Division of Clinical Laboratory of Eastern Hepatobiliary Surgery Hospital by standard procedures. 


\section{HCC Tissue Samples}

Liver specimens were obtained from primary HCC patients with HBV infection who received surgical resection in Eastern Hepatobiliary Surgery Hospital of the Second Military Medical University (Shanghai, China) with the approval of The Human Research Committee of University and with the patients' consents.

\section{Statistical Analysis}

Results are expressed as mean \pm SD. Statistical evaluation was carried out by one-way analysis of variance (ANOVA) followed by Student-Newman-Keuls test. Correlation between two variables was calculated by Spearman rank correlation coefficient. A value of $\mathrm{p}<$ 0.05 was considered to be statistically significant.

\section{Additional material}

Additional file 1: Figure S1 -The expression of flag-Mcl-1 in whole liver extracts. $\mathrm{HBx}$-Tg mice were subjected to a single injection of $\mathrm{Mcl}-$ 1-expressing plasmid ( $\mathrm{p} 3 \times$ flag-Mcl-1) or control plasmid (p3xflag) by tail vein. Two days later, whole liver extracts were probed with ant-Flag antibody. Figure $\mathrm{S} 2$-The expression and mitochondria translocation of Bax/Bak in $\mathrm{HBx}$-expressing cells following $\mathrm{H}_{2} \mathrm{O}_{2}$ treatment. (A) Indicated cells $\left(1 \times 10^{7}\right)$ were treated with or without $\mathrm{H}_{2} \mathrm{O}_{2}(400 \mu \mathrm{M})$ for $15 \mathrm{hr}$ followed by subjected to cellular fractionation. Whole cell lysates, cytosolic and mitochondrial fractions were subjected to Western blot analysis and probed with anti-Bax or anti-Bak antibody. (Cyto: cytosolic; Mito: mitochondrial). (B) SMMC-7721 cells were transiently transfected with p3.8II or p3.8Ilxm for $36 \mathrm{hr}$ followed by treated with $\mathrm{H}_{2} \mathrm{O}_{2}(400 \mu \mathrm{M})$ for additional $15 \mathrm{hr}$. Then whole cell lysates, cytosolic and mitochondrial fractions were subjected to Western blot assay and probed with indicated antibodies. (Cyto: cytosolic; Mito: mitochondrial).

\begin{abstract}
Abbreviations
HBV: hepatitis B virus; HBX: HBV X protein; HCC: human hepatocellular caricinoma; $\mathrm{Mcl}-1$ : myeloid cell leukemia-1; PARP: poly (ADP-ribose) polymerase; ROS: reactive oxygen species; GSH: reduced glutathione; GSSG: oxidized glutathione; BHA: butylated hydroxyanisole; hMTH1: human MutT homolog 1; MnSOD: manganese superoxide dismutase; $\mathrm{H}_{2} \mathrm{O}_{2}$ : peroxide hydrogen; I/R: ischemia/reperfusion; DHE: dihydroethidine; TUNEL: terminal deoxynucleotidyl transferase dUTP nick end labeling; FACS: fluorescence activated cell sorting; RT-PCR: reverse transcription-polymerase chain reaction; Tg mice: Transgenic mice; WT: wide type; Ad: Adenovirus; M.O.I.: multiplicity of infection; H.E.: hematoxyli-eosin; DMSO: dimethylsulfoxide; SD: standard deviation.
\end{abstract}

\section{Acknowledgements}

We thank Prof. Mujun Zhao, Mian Wu and Xiao Yang for providing the plasmids and transgenic mice. We are grateful to Dongping Hu, Dan Cao and Kun Wu for their technical assistance. This research was supported by the projects from the state Key project for liver cancer (2008ZX10002017,019,024), National Science Fund for Distinguished Young Scholars (30921006), Key Program of National Natural Science Foundation of China (90713032), China Postdoctoral Science Foundation (No.20100471766) and the grants from the government of Shanghai (No. 09CG33, 10QA1408700).

\section{Author details}

${ }^{1}$ International Co-operation Laboratory on Signal Transduction, Eastern Hepatobiliary Surgery Institute, Second Military Medical University, Shanghai, China. ${ }^{2}$ Department of Surgery, Eastern Hepatobiliary Surgery Hospital, Shanghai, China. ${ }^{3}$ State Key Laboratory for Oncogenes and Related Genes,
Cancer Institute of Ren Ji Hospital, Shanghai Jiao Tong University, Shanghai, China.

\section{Authors' contributions}

LH, LC and GZY contributed equally to this work. All authors read and approved the final manuscript.

\section{Competing interests}

The authors declare that they have no competing interests.

Received: 16 September 2010 Accepted: 20 April 2011

Published: 20 April 2011

\section{References}

1. Kim CM, Koike K, Saito I, Miyamura T, Jay G: HBx gene of hepatitis B virus induces liver cancer in transgenic mice. Nature 1991, 351:317-320.

2. Murakami S: Hepatitis $B$ virus $X$ protein: a multifunctional viral regulator. J Gastroenterol 2001, 36:651-660.

3. Tang H, Da L, Mao Y, Li Y, Li D, Xu Z, Li F, Wang Y, Tiollais P, Li T, Zhao M: Hepatitis $B$ virus $X$ protein sensitizes cells to starvation-induced autophagy via up-regulation of beclin 1 expression. Hepatology 2009, 49:60-71.

4. $X u$ J, Yun $X$, Jiang J, Wei $Y$, Wu Y, Zhang W, Liu Y, Wang W, Wen Y, Gu J: Hepatitis $B$ virus $X$ protein blunts senescence-like growth arrest of human hepatocellular carcinoma by reducing Notch1 cleavage. Hepatology 2010, 52:142-154.

5. Malhi H, Gores GJ: Cellular and molecular mechanisms of liver injury. Gastroenterology 2008, 134:1641-1654.

6. Guicciardi ME, Gores GJ: Apoptosis: a mechanism of acute and chronic liver injury. Gut 2005, 54:1024-1033.

7. Su F, Schneider RJ: Hepatitis B virus HBx protein sensitizes cells to apoptotic killing by tumor necrosis factor alpha. Proc Natl Acad Sci USA 1997, 94:8744-8749.

8. Liang X, Liu Y, Zhang Q, Gao L, Han L, Ma C, Zhang L, Chen YH, Sun W: Hepatitis B virus sensitizes hepatocytes to TRAlL-induced apoptosis through Bax. J Immunol 2007, 178:503-510.

9. Lee YI, Hwang JM, Im JH, Lee YI, Kim NS, Kim DG, Yu DY, Moon HB, Park SK: Human hepatitis $B$ virus-X protein alters mitochondrial function and physiology in human liver cells. J Biol Chem 2004, 279:15460-15471.

10. Kim WH, Hong F, Jaruga B, Zhang ZS, Fan SJ, Liang TJ, Gao B: Hepatitis B virus $X$ protein sensitizes primary mouse hepatocytes to ethanol- and TNFalpha-induced apoptosis by a caspase-3-dependent mechanism. Cell Mol Immunol 2005, 2:40-48

11. Terradillos $O$, de La Coste A, Pollicino T, Neuveut C, Sitterlin D, Lecoeur $H$ Gougeon ML, Kahn A, Buendia MA: The hepatitis B virus X protein abrogates $\mathrm{BCl}$-2-mediated protection against Fas apoptosis in the liver. Oncogene 2002, 21:377-386.

12. Lee AT, Ren J, Wong ET, Ban KH, Lee LA, Lee CG: The Hepatitis B Virus $X$ Protein Sensitizes HepG2 Cells to UV Light-induced DNA Damage. J Biol Chem 2005, 280:33525-33535.

13. Terradillos $\mathrm{O}$, Pollicino $\mathrm{T}$, Lecoeur $\mathrm{H}$, Tripodi M, Gougeon ML, Tiollais P, Buendia MA: p53-independent apoptotic effects of the hepatitis $B$ virus HBx protein in vivo and in vitro. Oncogene 1998, 17:2115-2123.

14. Wiseman $H$, Halliwell B: Damage to DNA by reactive oxygen and nitrogen species: Role in inflammatory disease and progression to cancer. Biochem J 1996, 313:17-29.

15. Kaplowitz N: Mechanisms of liver cell injury. J Hepatol 2000, 32:39-47.

16. Shirakata Y, Koike K: Hepatitis B Virus X Protein Induces Cell Death by Causing Loss of Mitochondrial Membrane Potential. J Biol Chem 2003, 278:22071-22078.

17. Hagen TM, Huang S, Curnutte J, Fowler P, Martinez V, Wehr CM, Ames BN, Chisari FV: Extensive oxidative DNA damage in hepatocytes of transgenic mice with chronic active hepatitis destined to develop hepatocellular carcinoma. Proc Natl Acad Sci USA 1994, 91:12808-12812.

18. Youle RJ, Strasser A: The BCL-2 protein family: opposing activities that mediate cell death. Nat Rev Mol Cell Biol 2008, 9:47-59.

19. Gross A, McDonnell JM, Korsmeyer SJ: BCL-2 family members and the mitochondria in apoptosis. Genes Dev 1999, 13:1899-1911.

20. Michels J, Johnson PW, Packham G: Mcl-1. Int J Biochem Cell Biol 2005 37:267-271. 
21. Opferman JT, Iwasaki H, Ong CC, Suh H, Mizuno S, Akashi K, Korsmeyer SJ: Obligate role of anti-apoptotic MCL-1 in the survival of hematopoietic stem cells. Science 2005, 307:1101-1104.

22. Opferman JT, Letai A, Beard C, Sorcinelli MD, Ong CC, Korsmeyer SJ: Development and maintenance of $B$ and $T$ lymphocytes requires antiapoptotic MCL-1. Nature 2003, 426:671-676.

23. Sieghart W, Losert D, Strommer S, Cejka D, Schmid K, RasoulRockenschaub S, Bodingbauer M, Crevenna R, Monia BP, PeckRadosavljevic M, Wacheck V: Mcl-1 overexpression in hepatocellular carcinoma: a potential target for antisense therapy. J Hepatol 2006, 44:151-157.

24. Schulze-Bergkamen $H$, Fleischer B, Schuchmann M, Weber A, Weinmann A, Krammer PH, Galle PR: Suppression of Mcl-1 via RNA interference sensitizes human hepatocellular carcinoma cells towards apoptosis induction. BMC Cancer 2006, 6:232.

25. Vick B, Weber A, Urbanik T, Maass T, Teufel A, Krammer PH, Opferman JT, Schuchmann M, Galle PR, Schulze-Bergkamen H: Knockout of myeloid cell leukemia-1 induces liver damage and increases apoptosis susceptibility of murine hepatocytes. Hepatology 2009, 49:627-636.

26. Weber A, Boger R, Vick B, Urbanik T, Haybaeck J, Zoller S, Teufel A, Krammer PH, Opferman JT, Galle PR, Schuchmann M, Heikenwalder M, Schulze-Bergkamen $\mathrm{H}$ : Hepatocyte-specific deletion of the antiapoptotic protein myeloid cell leukemia-1 triggers proliferation and hepatocarcinogenesis in mice. Hepatology 2010, 51:1226-1236.

27. Chen YC, Shen SC, Lee WR, Hsu FL, Lin HY, Ko CH, Tseng SW: Emodin induces apoptosis in human promyeloleukemic $\mathrm{HL}-60$ cells accompanied by activation of caspase 3 cascade but independent of reactive oxygen species production. Biochem Pharmacol 2002, 64:1713-1724

28. Inoshita S, Takeda K, Hatai T, Terada Y, Sano M, Hata J, Umezawa A, Ichijo H: Phosphorylation and inactivation of myeloid cell leukemia 1 by JNK in response to oxidative stress. J Biol Chem 2002, 277:43730-43734.

29. Sakurai T, He G, Matsuzawa A, Yu GY, Maeda S, Hardiman G, Karin M: Hepatocyte necrosis induced by oxidative stress and IL-1 alpha release mediate carcinogen-induced compensatory proliferation and liver tumorigenesis. Cancer Cell 2008, 14:156-165.

30. Hu L, Chen L, Li L, Sun H, Yang G, Chang Y, Tu Q, Wu M, Wang H: Hepatitis B Virus X Protein Enhances Cisplatin-Induced Hepatotoxicity via a Mechanism Involving Degradation of Mcl-1. J Virol 2011, 85:3214-3228.

31. Takehara T, Liu X, Fujimoto J, Friedman SL, Takahashi H: Expression and role of $\mathrm{Bcl}-\mathrm{xL}$ in human hepatocellular carcinomas. Hepatology 2001 34:55-61.

32. Herrant $M$, Jacquel $A$, Marchetti $S$, Belhacène $N$, Colosetti $P$, Luciano F, Auberger $\mathrm{P}$ : Cleavage of $\mathrm{Mcl}-1$ by caspases impaired its ability to counteract Bim-induced apoptosis. Oncogene 2004, 23:7863-7873.

33. Michels J, O'Neill JW, Dallman CL, Mouzakiti A, Habens F, Brimmell M, Zhang KY, Craig RW, Marcusson EG, Johnson PW, Packham G: Mcl-1 is required for Akata6 B-lymphoma cell survival and is converted to a cell death molecule by efficient caspase-mediated cleavage. Oncogene 2004, 23:4818-4827.

34. Derouet M, Thomas L, Moulding DA, Akgul C, Cross A, Moots RJ, Edwards SW: Sodium Salicylate Promotes Neutrophil Apoptosis by Stimulating Caspase-Dependent Turnover of Mcl-1. J Immunol 2006, 176:957-965.

35. Weng C, Li Y, Xu D, Shi Y, Tang H: Specific cleavage of Mcl-1 by caspase3 in tumor necrosis factor-related apoptosis-inducing ligand (TRAIL)induced apoptosis in Jurkat leukemia T cells. J Biol Chem 2005, 280:10491-10500.

36. Jüngst $C$, Cheng B, Gehrke R, Schmitz V, Nischalke HD, Ramakers J, Schramel $P$, Schirmacher $P$, Sauerbruch $T$, Caselmann WH: Oxidative damage is increased in human liver tissue adjacent to hepatocellular carcinoma. Hepatology 2004, 39:1663-1672.

37. Lim SO, Gu JM, Kim MS, Kim HS, Park YN, Park CK, Cho JW, Park YM Jung G: Epigenetic changes induced by reactive oxygen species in hepatocellular carcinoma: methylation of the E-cadherin promoter. Gastroenterology 2008, 135:2128-2140, 2140.e1-8.

38. Allen RG, Tresini M: Oxidative stress and gene regulation. Free Radic Biol Med 2000, 28:463-499.

39. Woo RA, Poon RY: Activated oncogenes promote and cooperate with chromosomal instability for neoplastic transformation. Genes Dev 2004, 18:1317-1330
40. Toyokuni S: Novel aspects of oxidative stress-associated carcinogenesis. Antioxid Redox Signal 2006, 8:1373-1377.

41. Hikita H, Takehara T, Shimizu S, Kodama T, Li W, Miyagi T, Hosui A, Ishida H, Ohkawa K, Kanto T, Hiramatsu N, Yin XM, Hennighausen L, Tatsumi T, Hayashi N: Mcl-1 and $\mathrm{BCl}-\mathrm{xL}$ cooperatively maintain integrity of hepatocytes in developing and adult murine liver. Hepatology 2009, 50:1217-1226.

42. Tang H, Oishi N, Kaneko S, Murakami S: Molecular functions and biological roles of hepatitis B virus X protein. Cancer Sci 2006, 97:977-983.

43. Arbuthnot $P$, Capovilla A, Kew M: Putative role of hepatitis $B$ virus $\mathbf{X}$ protein in hepatocarcinogenesis: effects on apoptosis, DNA repair, mitogen-activated protein kinase and JAK/STAT pathways. J Gastroenterol Hepatol 2000, 15:357-368.

44. Willis SN, Chen L, Dewson G, Wei A, Naik E, Fletcher Jl, Adams JM, Huang DC: Proapoptotic Bak is sequestered by $\mathrm{Mcl}-1$ and $\mathrm{BCl}-\mathrm{xL}$, but not BCl-2, until displaced by BH3-only proteins. Genes Dev 2005, 19:1294-1305.

45. Adams JM, Cory S: The Bcl-2 apoptotic switch in cancer development and therapy. Oncogene 2007, 26:1324-1337.

46. Kim H, Rafiuddin-Shah M, Tu HC, Jeffers JR, Zambetti GP, Hsieh JJ, Cheng EH: Hierarchical regulation of mitochondrion-dependent apoptosis by BCL-2 subfamilies. Nat Cell Biol 2006, 8:1348-1358.

47. Miao J, Chen GG, Chun SY, Lai PP: Hepatitis B virus X protein induces apoptosis in hepatoma cells through inhibiting $\mathrm{BCl}-\mathrm{xL}$ expression. Cancer Lett 2006, 236:115-124.

48. Cheng AS, Yu J, Lai PB, Chan HL, Sung JJ: COX-2 mediates hepatitis B virus $X$ protein abrogation of $\mathrm{p} 53$-induced apoptosis. Biochem Biophys Res Commun 2008, 374:175-180.

49. Ahmad KA, Iskandar KB, Hirpara JL, Clement MV, Pervaiz S: Hydrogen peroxide-mediated cytosolic acidification is a signal for mitochondrial translocation of Bax during drug-induced apoptosis of tumor cells. Cancer Res 2004, 64:7867-7878.

50. Rahmani M, Davis EM, Bauer C, Dent P, Grant S: Apoptosis induced by the kinase inhibitor BAY 43-9006 in human leukemia cells involves downregulation of Mcl-1 through inhibition of translation. J Biol Chem 2005, 280:35217-35227.

51. Wang WH, Grégori G, Hullinger RL, Andrisani OM: Sustained activation of p38 mitogen-activated protein kinase and c-Jun N-terminal kinase pathways by hepatitis $B$ virus $X$ protein mediates apoptosis via induction of Fas/FasL and tumor necrosis factor (TNF) receptor 1/TNFalpha expression. Mol Cell Bio 2004, 24:10352-10365.

52. Tanaka Y, Kanai F, Ichimura T, Tateishi K, Asaoka Y, Guleng B, Jazag A, Ohta M, Imamura J, Ikenoue T, ljichi H, Kawabe T, Isobe T, Omata M: The hepatitis B virus X protein enhances AP-1 activation through interaction with Jab1. Oncogene 2006, 25:633-642.

53. Clippinger AJ, Bouchard MJ: Hepatitis B virus $\mathrm{HBx}$ protein localizes to mitochondria in primary rat hepatocytes and modulates mitochondrial membrane potential. J Virol 2008, 82:6798-6811.

54. Maelfait J, Beyaert R: Non-apoptotic functions of caspase-8. Biochem Pharmacol 2008, 76:1365-1373.

55. Szatrowski TP, Nathan CF: Production of large amounts of hydrogen peroxide by human tumor cells. Cancer Res 1991, 51:794-798.

56. Toyokuni S, Okamoto K, Yodoi J, Hiai H: Persistent oxidative stress in cancer. FEBS Lett 1995, 358:1-3.

57. Clément MV, Hirpara $\lrcorner$, Pervaiz S: Decrease in intracellular superoxide sensitizes $\mathrm{BCl}$-2-overexpressing tumor cells to receptor and druginduced apoptosis independent of the mitochondria. Cell Death Differ 2003, 10:1273-1285.

58. Pervaiz S, Cao J, Chao OS, Chin YY, Clément MV: Activation of the RacGTPase inhibits apoptosis in human tumor cells. Oncogene 2001, 20:6263-6268.

59. Chen L, Yan HX, Chen J, Yang W, Liu Q, Zhai B, Cao HF, Liu SQ, Wu MC, Wang HY: Negative regulation of c-Myc transcription by pancreas duodenum homeobox-1. Endocrinology 2007, 148:2168-2180.

60. Chen L, Yan HX, Yang W, Hu L, Yu LX, Liu Q, Li L, Huang DD, Ding J, Shen F, Zhou WP, Wu MC, Wang HY: The role of microRNA expression pattern in human intrahepatic cholangiocarcinoma. J Hepatol 2009, 50:358-369.

61. Wang Y, Cui F, Lv Y, Li C, Xu X, Deng C, Wang D, Sun Y, Hu G, Lang Z, Huang C, Yang X: HBsAg and HBx Knocked Into the p21 Locus Causes Hepatocellular Carcinoma in Mice. Hepatology 2004, 39:318-324. 
62. Liu F, Song Y, Liu D: Hydrodynamics-based transfection in animals by systemic administration of plasmid DNA. Gene Ther 1999, 6:1258-1266.

63. National Research Council: Guide for the care and use of laboratory animals. National Academy Press, Washington, DC; 1996.

doi:10.1186/1476-4598-10-43

Cite this article as: Hu et al:: HBx Sensitizes Cells to Oxidative Stressinduced Apoptosis by Accelerating the Loss of Mcl-1 Protein via Caspase-3 Cascade. Molecular Cancer 2011 10:43.

Submit your next manuscript to BioMed Central and take full advantage of:

- Convenient online submission

- Thorough peer review

- No space constraints or color figure charges

- Immediate publication on acceptance

- Inclusion in PubMed, CAS, Scopus and Google Scholar

- Research which is freely available for redistribution

Submit your manuscript at www.biomedcentral.com/submit
C Biomed Central 